\title{
Review Article on Effects of Moringa on Central Nervous System
}

\author{
Mohd Faiz Khan, Sanjay Yadav, Sugato Banerjee* \\ Department of Pharmacology and Toxicology, National Institute of Pharmaceutical Education and Research, Kolkata, West Bengal, INDIA.
}

\begin{abstract}
Moringa oleifera is a plant of high value because of its wide range of applications, it is an indigenous plant widely distributed in India and other parts of the world. It contains a wide variety of phytoconstituents viz. flavonoids, saponins, sterols, anthraquinones, tannins and terpenoids. It possesses antidiabetic, antitumor, antibacterial, antihypertensive and other activities of medicinal use. Studies have also found its activity on central nervous system, in neurodegenerative diseases like Alzheimer's disease, Parkinson's disease, neuropathic pain, Multiple sclerosis, ischemia, depression and it has shown to promote neurite outgrowth, and reported to possesses neuroprotective action. Here we review the potential activity of Moringa on
\end{abstract}

central nervous system and against various neurodegenerative disorders. Key words: Alzheimer's disease, Depression, Moringa, Neurodegenerative diseases, Neuronal development, Oxidative stress.

Correspondence

Dr. Sugato Banerjee,

Department of Pharmacology and Toxicology, NIPER, Kolkata-700054, West Bengal, INDIA.

Email id: banerjeesugato1@gmail.com

DOI: 10.5530/jyp.2021.13.83

\section{INTRODUCTION}

Moringa oleifera also known as drumstick or horseradish tree, ${ }^{1}$ is native of western Himalaya, India, Pakistan, Africa, and Arabia ${ }^{2,3}$ the different types of species and their geographical distribution with trivial names are given in Table 1. Almost all parts of the plants are used as drug. Various phytochemicals viz. alkaloids, steroids, amino acids, flavonoids, carbamates, carotenoids, cyanates, isocyanates, phenolic esters, proteins and essential oils have been reported. ${ }^{6}$ Medicinally it possesses antitumor, antiulcer, antipyretic, antiepileptic, antibacterial, antifungal, antidiabetic, diuretic, hepatoprotective, antihypertensive, cholesterol lowering, antispasmodic, cardiac stimulant and antioxidant activities. $^{6}$

Many researchers have found that moringa have varieties of central nervous system activities which includes anticonvulsant, antiepileptic, ${ }^{7}$ anti-depressant, ${ }^{8}$ against Alzheimer's disease, ${ }^{9}$ as cognitive enhancer, ${ }^{10}$ while also increasing sleeping time by increasing serotonin level ${ }^{11}$ and also against neurotoxicity. ${ }^{12,13}$

\section{CHEMISTRY OF MORINGA}

Moringa is rich in nutrition owing to the presence of variety of phytochemicals present in barks, leaves, seeds, flowers, roots and immature pods. ${ }^{14}$ Moringa contains phytochemicals such as tannins, sterols, terpenoids, flavonoids, saponins, and anthraquinones. ${ }^{14}$ Flavonoids present in $M$. oleifera leaves are kaempferol, quercetin, isorhamnetin and apigenin are the most common flavonoids which exist in abundance as glycosides attached to a wide spectrum of sugar moieties (e.g., acetyl dihexose, hexose, and rutinoside).$^{15}$ Alkaloids and reducing sugar present include glucosinolates, isothiocyanates, glycoside compounds and glycerol-1-9-octadecanoate. ${ }^{16}$ Different type of phytochemicals found in various parts of the plant is given in Table 2. Moringa oleifera leaf extract has been shown to regulate mono amine levels of brains, which may be useful in Alzheimer's disease. Aqueous extracts of moringa oleifera can be used as anticonvulsant. Its leaves can be used for studying penicillin induced convulsion, locomotor behavior, brain serotonin (5-HT), dopamine and norepinephrine level is evaluated. ${ }^{20}$

\section{MORINGA OLEIFERA AND CNS DISORDERS}

\section{Effect of Moringa on depression}

Kaur et al. evaluated the antidepressant effects of Moringa oleifera (alcoholic extract of leaves was used) in mouse model of depression. ${ }^{8}$ The authors concluded that oxidative stress in the brain can be the possible mechanism for anti-depressive activity of Moringa which was evaluated using forced swim, tail suspension tests. ${ }^{8}$

\section{Effect of Moringa on spatial memory}

Sutalangka et al. considering the antioxidant and nootropic effect of Moringa oleifera evaluated its effect on spatial memory and neuroprotection in animal model of age-related dementia using leaves extract of the plant. ${ }^{10}$ The study clearly showed that Moringa oleifera improved spatial memory and reduced neurodegeneration which could be due to its enhanced cholinergic action and reduction in oxidative stress. ${ }^{10}$ However, the main component of Moringa responsible for cognitive enhancement is yet to bet investigated. In other studies it was found that flavonoids are responsible for its anti neurodegeneration activity and helps in the normal functioning of the neurons. ${ }^{21}$

\section{Moringa and neurotoxicity}

Igado et al. observed the effect of methanolic extract of Moringa oleifera leaves on vanadium induced neurotoxicity in mice. ${ }^{13}$ This study indicates that Moringa oleifera leaves can work as a potential neuroprotective agent and can be used as an antidote in vanadium poisoning. In this study moringa reduced vanadium induced neuronal hypertrophy, myelin damage and increased oligodendrocyte density.

\section{Effect of Moringa on neuronal development}

Hannan et al. using primary hippocampal neuronal cultures observed the effects of ethanol extract of Moringa oleifera leaves. Neurite outgrowth was observed in Moringa oleifera leaf extract treated neuronal cell cultures in a dose dependent manner while increasing neuronal viability in vitro. It also accelerated neuronal differentiation and found to help 
Table 1: Different types of Moringa species and their geographical distribution.

\begin{tabular}{|c|c|c|}
\hline Species & Country & Trivial names \\
\hline M. oleifera Lam. $^{4}$ & India & Horseradish, Ben-oil, Drumstick, Kelor ${ }^{5}$ \\
\hline M. peregrina Forssk ${ }^{4}$ & Red Sea, Arabia & Ben tree ${ }^{5}$ \\
\hline M. longituba Engler ${ }^{4}$ & Kenya, Southeast Ethiopia, Somalia & Moringa tubiflora ${ }^{5}$ \\
\hline M. concanensis $\mathrm{Nimmo}^{4}$ & India & - \\
\hline M. stenopetala (Baker f.) Cufodontis ${ }^{4}$ & Kenya, Southwest Ethiopia, Somalia & Cabbage tree, Haleko, Shelagda, Shiferaw ${ }^{5}$ \\
\hline M. hildebrandtii Engler ${ }^{4}$ & Southwest Madagascar & Hildebrandt's Moringa $^{5}$ \\
\hline M. rivae Chiovenda ${ }^{4}$ & Kenya, Ethiopia & Swanjehro ${ }^{5}$ \\
\hline M. drouhardii Jumelle ${ }^{4}$ & Southern Madagascar & - \\
\hline M. arborea Verdcourt ${ }^{4}$ & Kenya, Somalia & - \\
\hline M. borziana Matte $^{4}$ & Kenya, Somalia & - \\
\hline M. ovalifolia Dinter ex Berger ${ }^{4}$ & Namibia, Southwest Angola & Phantom Tree, Ghost Tree, African Moringo \\
\hline
\end{tabular}

Table 2: Phytochemicals present in different parts of the plant Moringa. ${ }^{17-19}$

\begin{tabular}{|c|c|c|c|}
\hline Sr.no & Plant part & Extract & Phytoconstituents \\
\hline 1. & Leaves & Aqueous and alcoholic & $\begin{array}{c}\text { Niazirin and niazirinin - nitrile glycoside, } \\
\text { 4-[(4'-O-acetylalpha-L-rhamnosyloxy)benzyl isothiocyanate } \\
\text { Niaziminin A, Niaziminin B, } \\
\text { 4-(alpha_1_rhamnopyranosyloxy)-benzylglucosinolate( Figure 1) } \\
\text { Quercetin-3-O-glucoside } \\
\text { Pyrrole alkaloid ( 40-hydroxyphenylethanamide) } \\
\text { Alpha and gamma-tocopherol }\end{array}$ \\
\hline 2. & Seeds & $\begin{array}{l}\text { Aqueous and hydro- } \\
\text { alcoholic }\end{array}$ & $\begin{array}{l}\text { 4-(alpha-L-rhamnopyranosyloxy), Benzylglucosinolate, } \\
\text { Moringine (Figure 2), Methionine, cysteine }\end{array}$ \\
\hline 3. & Pods & Hydro-alcoholic & Isothiocyanate, Nitrites, Thiocarbamates, Methyl-p-hydroxybenzoate, Beta-sitosterol(Figure 3) \\
\hline 4. & Bark & Alcoholic & 4-(alpha-L-rhamnopyranosyloxy)benzylgiucosinolate \\
\hline 5. & Flower & Hydroalcholic & D-glucose, Quercetin, Isoquercetin, Kaemopherol, Ascorbic acid, Protein, D-mannose \\
\hline 6. & Root & Alcoholic & Moringine, Moringinine, Spirachin, 1,3-dibenzyl urea, Alpha-phellandrene, p-cymene(Figure 4) \\
\hline 7. & Stem & $\begin{array}{c}\text { Aqueous and } \\
\text { hydroalcoholic }\end{array}$ & 4-hydroxyl mullein, Vanillin, Octacosonoic acid, Beta-sitosterone, Beta-sitosterol \\
\hline
\end{tabular}<smiles>CC(=O)OC1C(C)OC(Oc2ccc(CN=C=S)cc2)C(O)C1O</smiles>

Figure 1: 4-(alpha_1_rhamnopyranosyloxy)-benzylglucosinolate.

in synaptogenesis and increase the density of pre- and postsynaptic terminals. The study found that beta-carotene one of the major components of Moringa was responsible for neurite outgrowth. ${ }^{22}$

\section{Effect of Moringa on Alzheimer's Disease}

Mahaman et al. studied the effect of Moringa oleifera (MO) leaves extract on hyperhomocysteinemia (HHcy) induced Alzheimer's disease like

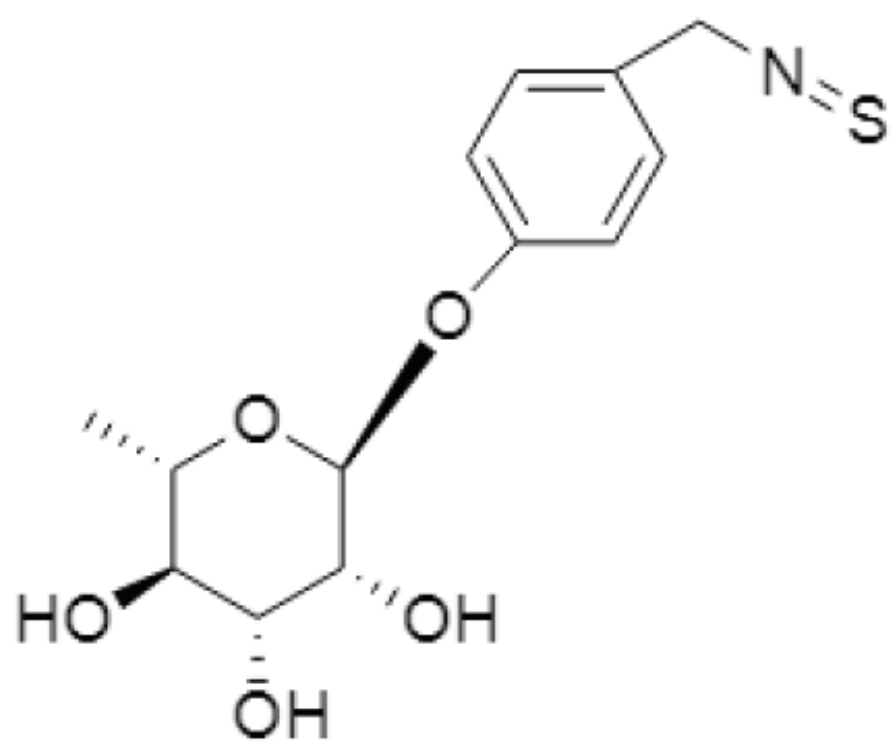

Figure 2: Moringine. 


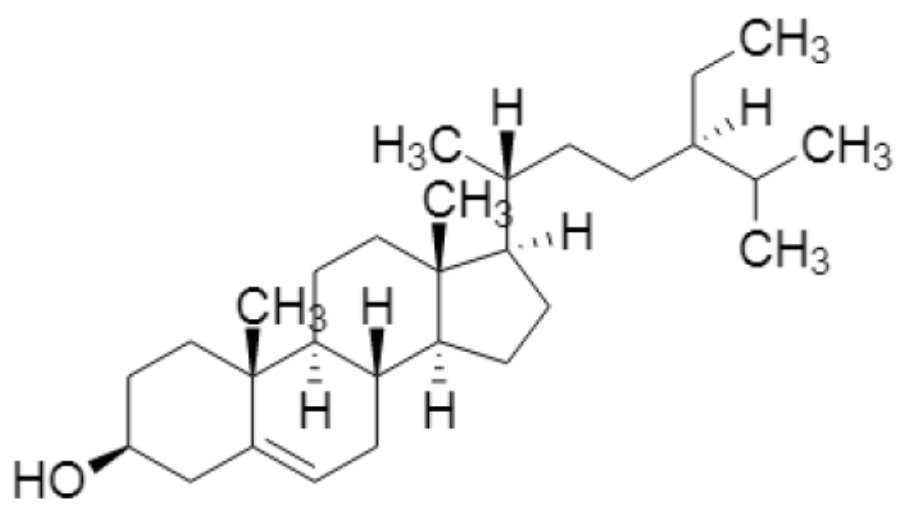

Figure 3: Beta-sitosterol.

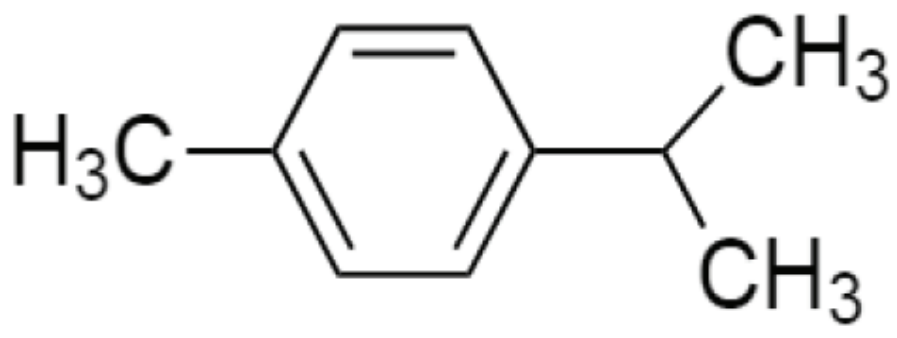

Figure 4: p-cymene.

Parts of plants that are used for various treatments. ${ }^{17}$

\begin{tabular}{|c|c|}
\hline Part of plant & Activity \\
\hline \multirow[t]{5}{*}{ Leaves } & Antioxidant \\
\hline & Antiepileptic \\
\hline & Anti-diabetic \\
\hline & Cardiovascular \\
\hline & Anticancer \\
\hline \multirow[t]{2}{*}{ Roots } & Antifertility \\
\hline & Anti-inflammatory \\
\hline \multirow[t]{2}{*}{ Bark } & Anti urolithiatic \\
\hline & Anti-inflammatory \\
\hline \multirow[t]{3}{*}{ Seed } & Anti-asthmatic \\
\hline & Hepatoprotective \\
\hline & Anticancer \\
\hline
\end{tabular}

pathology in rats. Moringa oleifera leaf extract reduced HHcy induced oxidative stress, tau hyperphosphorylation, amyloid beta accumulation. As a result, it increased synaptic protein levels and eventually reversed HHcy induced memory impairment. ${ }^{23}$

\section{Effect of Moringa on ischemic stroke}

Kirisattayakul et al. studied the effect of Moringa oleifera leaf extract on focal ischemic stroke induced by right middle cerebral artery occlusion (Rt. MCAO) in male Wistar rats. ${ }^{24}$ The study showed functional recovery of brain dysfunction after Rt. MCAO. It was observed that MCAO caused significant reduction of neurological scores this was reversed by Moringa leaf extract after 14 and 21 days of treatment. It improved motor performance, decreased brain infarction volume in cortex and subcortex and reduced neuroinflammatory changes in a dose dependent manner. ${ }^{24}$ It was suggested that the decrease in oxidative stress by Moringa in cerebral cortex may be due to its anti-oxidant and anti-inflammatory actions. ${ }^{24-26}$

\section{Effect of Moringa on Multiple Sclerosis}

Omotoso et al. conducted research to evaluate the ameliorative capability of $M$. oleifera in cuprizon (CPZ) (animal models of Multiple Sclerosis) induced behavioral and histopathological (cortex and hippocampus) alterations of waster rats. ${ }^{27} \mathrm{CPZ}$ reduced the short-term memory in mice. But when they were treated with $M$. oleifera they were able to restore the working memory of the experimental animal as measured by percentage correct alteration of animals using Y maze test. ${ }^{27}$ It was concluded that the antioxidant property of $M$. oleifera was primarily responsible for its neuroprotective actions. Giacoppo et al. studied the effect of topical moringin cream on neuropathic pain in Multiple sclerosis (MS) using EAE (Experimental autoimmune encephalomyelitis) mice. ${ }^{28} 2 \%$ moringin cream protected the myelin sheath and showed a marked remyelination and reduced neuropathic pain..$^{28}$ It also reduced spinal cord IL-17, TNF- $\alpha$ and IFN- $\gamma$ expression while increasing IL-10 expression. ${ }^{28}$ The cream also enhanced the downregulation of glutamate transporters which are involved in neuropathic pain in EAE mice and MS patients. ${ }^{28}$

\section{Effect of Moringa on Parkinson's disease}

Giapocco et al. conducted a research to estimate the possible neuroprotective effect of isothiocyanate isolated from Moringa oleifera in the treatment and prevention of Parkinson's disease. For this study Parkinson disease was induced in C57BL/6 mice by administering 1-methyl4-10-phenyl-1, 2, 3, 6-tetrahydropyridine (MPTP). For 1 week the mice were daily pretreated with moringin and glucomoringin (GMG) and behavior evaluation was done to record motor deficits in MPTP mice. ${ }^{29}$

Dendrites were clearly reduced in neurons from substantia nigra of MPTP mice. Moringin prevented this neuronal damage. It was also observed that moringin pretreatment protected dopaminergic neurons by restoring the tyrosine hydroxylase levels. ${ }^{29}$ The primary mechanisms involved in the given process was by reduction of proinflammatory cytokines, iNOS levels and eventual reduction of caspase activation.

\section{Mechanisms of Action of Moringa}

Many studies have directed the idea of mechanism of action of Moringa for its neuroprotective effect towards its antioxidant property as it has been shown to reduce oxidative stress in depression, neurodegeneration, Alzheimer's disease and ischemic stroke. , $^{8,10,23,24}$

Antioxidants work as a neuroprotective agent in following ways:

- They prevent the generation of ROS (Reactive Oxygen Species), capture and block the generated free radicals and can work enzymatically and non-enzymatically. ${ }^{30,31}$ In the former system superoxide dismutase, glutathione peroxidase and catalase are included. In the latter system reduced thiol, lipo and hydro soluble metabolic compounds are included. ${ }^{30,32}$ Superoxide dismutase (SOD) of enzymatic defense system reduces the superoxide radical anion to $\mathrm{H} 2 \mathrm{O} 2$ through oxidative decay mechanism. ${ }^{30}$ And this $\mathrm{H} 2 \mathrm{O} 2$ decompose into water and oxygen by catalase (CAT) and glutathione peroxidase (GPx), ${ }^{30}$ Moringa may potentiate this defense system by increasing the activity of SOD, CAT and GPx (Figure 5A).

- They repair the oxidatively damaged biomolecules (nucleic acids), oxidized lipids by specific enzymes. Remove oxidized proteins through the proteolytic systems. ${ }^{31}$ Proteasome is the major proteo- 


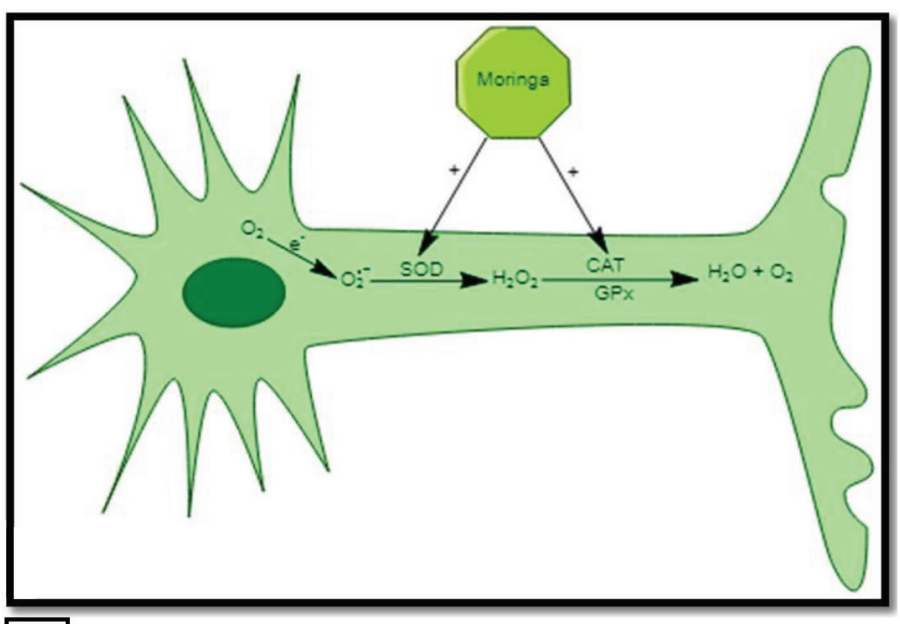

$\mathbf{A}$

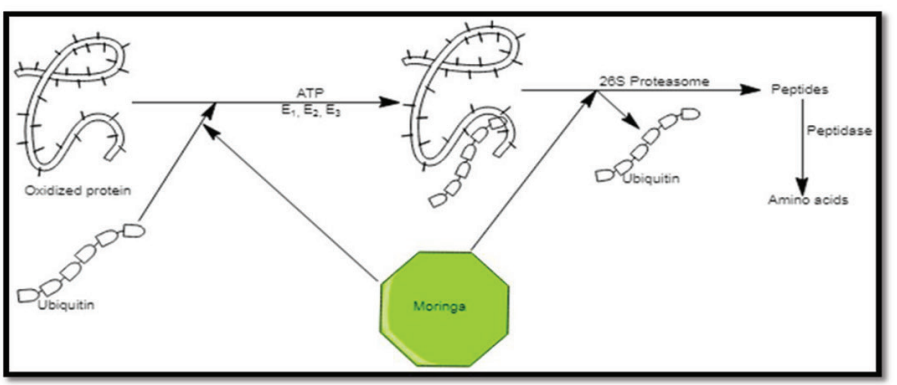

B

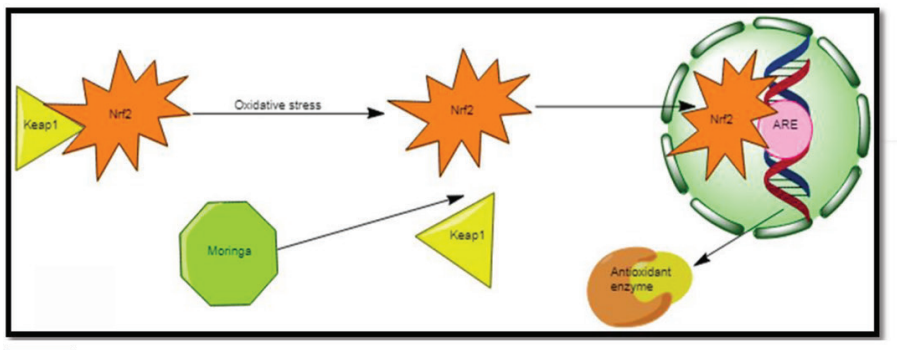

C

Figure 5: Mechanism of actions of Moringa. A: Enzymatic defense system of antioxidant, Moringa may increase the activity of SOD, CAT and GPX. B: Ubiquitin Proteasome Pathway (UPP), in this Moringa can act potentiate the conjugation of $\mathrm{Ub}$ and oxidized proteins and increases the activity of $26 \mathrm{~S}$ proteasome. C: Nrf2/ Keap1 pathway here Moringa decreases Keap1 expression thus facilitates Nrf2 nuclear translocation.

lytic system which is responsible for the degradation of oxidized cytosolic and nuclear proteins. ${ }^{33}$ Proteasome degrades the proteins through ubiquitin (Ub)- proteasome pathway (UPP), in this $\mathrm{Ub}$ conjugates to the oxidized proteins through an ATP- dependent pathway which includes three enzymes. ${ }^{34}$ The $26 \mathrm{~S}$ proteasome recognizes the complex and the protein enters the proteasome detaching from Ub and get digested to peptides which are further degraded to amino acids by cytoplasmic peptidase, ${ }^{34}$ Moringa can show its action by potentiating the conjugation of $\mathrm{Ub}$ to oxidized protiens and may also increase the activity of $26 \mathrm{~S}$ proteasome to degrade the oxidized proteins (Figure 5B).
Moringa is a rich source of flavonoids, phenols, carotenoids and $\beta$-sitosterol. ${ }^{22}$ Flavonoids in it may be involved in its neuroprotective action. Baicalein which is a flavonoid derived from Scutellaria baicalensis has been shown to attenuate neuronal damage in the hippocampus in global brain ischemia mice model by inhibiting MMP- 9 activity. ${ }^{35} \beta$-carotene was found to be the major component of MOE and it promotes neurite outgrowth. ${ }^{22}$ Chen et al. found $\beta$-carotene as neuroprotective and it also modulates the Nrf2/Keap 1 mediated antioxidant pathway hence alleviated oxidative stress in the traumatic brain injury model. ${ }^{36}$ It is found to potentiate Nrf2 nuclear translocation and increases the expression of downstream target genes which ultimately reduces Keap1 expression. ${ }^{36}$ Keap 1 is a negative regulator which tightly regulates Nrf2 activity and it binds to Nrf2 to retain it in the cytoplasm, oxidative stress induces $\mathrm{Nrf2}$, it dissociates from Keap1 and translocate to the nucleus and activates ARE-dependent gene expression which produces antioxidant enzymes. ${ }^{37} \beta$-carotene increases Nrf2 translocation and decreases Keap1 expression. ${ }^{36} \beta$-carotene being a major constituent of Moringa we may conclude that one of its antioxidant mechanisms include activation of NRf2 signaling (Figure 5C).

\section{TOXICITY OF MORINGA}

The complete toxicity profile of moringa is yet to be studied. However, the following toxicities of the plant has been reported. The root bark of Moringa contains moringinine as well as 2 alkaloids which are hypotensive in nature. Positive inotropic effect is produced at lower concentration while negative inotropic effect is produced at higher concentration which was revealed in the study by using isolated frog heart. ${ }^{38}$ Ethanolic fraction of Moringa oliefera was found to contain Niazinin A, Niazimicin and Niaziminin $\mathrm{A}+\mathrm{B} .{ }^{39}$ They produced bradycardia and hypotensive effects in rats while in isolated guinea pig atria it produced negative chronotropic and inotropic effects. ${ }^{38}$ The moringa tree bark may be lethal and causes violent uterine contractions. The methanolic extraction of moringa oleifera roots was found to have $0.2 \%$ alkaloids. ${ }^{40}$ In mice, hematologic parameter was studied by intraperitoneal doses of crude extract on liver and kidney by daily therapeutic dose $(3.5,4.6$ and $7.0 \mathrm{mg} / \mathrm{kg})$ and multiple weekly doses $(35,46,70 \mathrm{mg} / \mathrm{kg})$. The result indicated that daily therapeutic low dose $(3.5,4.6 \mathrm{mg} / \mathrm{kg})$ and weekly low dose $(3.5 \mathrm{mg} / \mathrm{kg})$ did not produce adverse effects on liver and kidney whereas daily therapeutic high dose $(7 \mathrm{mg} / \mathrm{kg})$ and weekly moderate/high dose $(>46 \mathrm{mg} / \mathrm{kg})$ affected the liver and kidney functions. ${ }^{38,41}$ When extracts of root bark of Moringa oleifera were used intraperitoneally in rodents (mice), the LD50 is $500 \mathrm{mg} / \mathrm{kg}$ while TDLo was found to be $184 \mathrm{mg} / \mathrm{kg}$. Even after the removal of the root bark (toxic) the trunk contains the alkaloid spirochin which may cause nerve paralysis upon regular consumption. ${ }^{38}$

\section{CONCLUSION}

From the above review it can be concluded that Moringa oleifera is a plant having versatile applications, many researches indicate that Moringa have a great potential in treating various neurodegenerative diseases and other CNS anomalies. Most of the study used the alcoholic extract of the plant leaves but the specific phytochemical responsible for the effect on CNS is yet to be found more research is required to identify the phytoconstituents. Some studies suggests that it may be beta carotene which is responsible for helping neurite outgrowth. Antioxidant activity of Moringa may protect against neurodegenerative disorders however its detailed mechanism of action is yet to be determined.

\section{ACKNOWLEDGEMENT}

We would like to acknowledge NIPER Kolkata for infrastructural support. 


\section{CONFLICT OF INTEREST}

The authors declare no conflict of interests.

\section{REFERENCES}

1. Anwar F, Latif S, Ashraf M, Gilani AH. Moringa oleifera: a food plant with multiple medicinal uses. Phytother Res. 2007;21(1):17-25. doi: 10.1002/ptr.2023, PMID 17089328

2. Mughal MH, Ali G, Srivastava PS, Iqbal M. Improvement of drumstick (Moringa pterygosperma Gaertn.) - a unique source of food and medicine through tissue culture. Hamdard Med. 1999;42:37-42.

3. Somali MA, Bajneid MA, Al-Fhaimani SS. Chemical composition and characteristics of Moringa peregrina seeds and seeds oil. J Am Oil Chem Soc. 1984;61(1):85-6. doi: 10.1007/BF02672051.

4. Bihrmann's Caudiciforms. Available from: http://www.bihrmann.com [cited 11/10/2021].

5. Abd Rani NZ, Husain K, Kumolosasi E. Moringa Genus: A review of phytochemistry and pharmacology. Front Pharmacol. 2018;9:108. doi: 10.3389/ fphar.2018.00108, PMID 29503616.

6. Al-Abri M, Ashique M, Ramkumar A, Nemmar A, Ali BH. Motor and behavioral effects of Moringa oleifera Leaf extract. Nat Prod Commun. 2018;13(1):89-92. doi: 10.1177/1934578X1801300126.

7. Bakre AG, Aderibigbe AO, Ademowo OG. Studies on neuropharmacological profile of ethanol extract of Moringa oleifera leaves in mice. J Ethnopharmacol. 2013;149(3):783-9. doi: 10.1016/j.jep.2013.08.006, PMID 23933316.

8. Kaur G, Invally M, Sanzagiri R, Buttar HS. Evaluation of the antidepressant activity of Moringa oleifera alone and in combination with fluoxetine. J Ayurveda Integr Med. 2015;6(4):273-9. doi: 10.4103/0975-9476.172384, PMID 26834427.

9. Ganguly R. Effect of Moringa Oleifera in Experimental Model of Alzheimer's Disease: Role of Antioxidants. Ann Neurosci. 2005;12(3):33-6. doi: 10.5214/ ans.0972.7531.2005.120301.

10. Sutalangka C, Wattanathorn J, Muchimapura S, Thukham-mee W. Moringa oleifera mitigates memory impairment and neurodegeneration in animal model of age-related dementia. Oxid Med Cell Longev. 2013;2013:695936. doi: $10.1155 / 2013 / 695936$

11. Ray K, Hazra R, Debnath PK, Guha D. Role of 5-hydroxytryptamine in Moringa oleifera induced potentiation of pentobarbitone hypnosis in albino rats. Indian J Exp Biol. 2004;42(6):632-5. PMID 15260119.

12. Giacoppo S, Galuppo M, Montaut S, lori R, Rollin P, Bramanti P, Mazzon E. An overview on neuroprotective effects of isothiocyanates for the treatment of neurodegenerative diseases. Fitoterapia. 2015;106:12-21. doi: 10.1016/j.fitote. 2015.08.001, PMID 26254971.

13. Igado OO, Andrioli A, Azeez IA, Girolamo F, Errede M, Aina OO, Glaser J, Holzgrabe U, Bentivoglio M, Olopade JO. The ameliorative effects of a phenolic derivative of Moringa oleifera leave against vanadium-induced neurotoxicity in mice [IBRO rep:164-82]. IBRO Rep. 2020;9:164-82. doi: 10.1016/j.ibror.2020.07.004, PMID 32803016.

14. Gopalakrishnan L, Doriya K, Kumar DS. Moringa oleifera: a review on nutritive importance and its medicinal application. Food Sci Hum Wellness. 2016;5(2):49-56. doi: 10.1016/j.fshw.2016.04.001.

15. Lin M, Zhang J, Chen X. Bioactive flavonoids in Moringa oleifera and their health-promoting properties. J Funct Foods. 2018;47:469-79. doi: 10.1016/j. jff.2018.06.011.

16. Berkovich L, Earon G, Ron I, Rimmon A, Vexler A, Lev-Ari S. Moringa Oleifera aqueous leaf extract down-regulates nuclear factor-kappaB and increases cytotoxic effect of chemotherapy in pancreatic cancer cells. BMC Complement Altern Med. 2013;13(1):212-9. doi: 10.1186/1472-6882-13-212.

17. Paikra BK, Dhongade HKJ, Gidwani B. Phytochemistry and Pharmacology of Moringa oleifera Lam. J Pharmacopuncture. 2017;20(3):194-200. doi: 10.3831/ KPI.2017.20.022, PMID 30087795.

18. Foidl N, Makkar HPS, Becker K. The potential use of Moringa oleifera for agriculture and industrial uses. Managua, Nicaragua; 2001. p. 1-20.

19. Sharma VR, Paliwal R, Sharma S. Phytochemical analysis and evaluation of antioxidant activities of hydroethanolic extract of Moringa oleifera Lam. J Pharm Res. 2011;4(2):554-7.

20. Tahiliani P, Kar A. Role of Moringa oleifera leaf extract in the regulation of thyroid hormone status in adult male and female rats. Pharmacol Res. 2000;41(3):319-23. doi: 10.1006/phrs.1999.0587, PMID 10675284

21. Youdim KA, Joseph JA. A possible emerging role of phytochemicals in improving age-related neurological dysfunctions: a multiplicity of effects. Free Radic Biol Med. 2001;30(6):583-94. doi: 10.1016/s0891-5849(00)00510-4, PMID 11295356.

22. Hannan MA, Kang JY, Mohibbullah M, Hong YK, Lee H, Choi JS, Choi IS, Moon IS Moringa oleifera with promising neuronal survival and neurite outgrowth promoting potentials. J Ethnopharmacol. 2014;152(1):142-50. doi: 10.1016/j. jep.2013.12.036, PMID 24389557.

23. Mahaman YAR, Huang $F$, Wu M, Wang Y, Wei Z, Bao J, Salissou MTM, Ke D, Wang Q, Liu R, Wang JZ, Zhang B, Chen D, Wang X. Moringa oleifera alleviates homocysteine-induced Alzheimer's disease-like pathology and cognitive impairments. J Alzheimers Dis. 2018:63(3):1141-59. doi: 10.3233/JAD-180091, PMID 29710724

24. Kirisattayakul W, Wattanathorn J, Tong-Un T, Muchimapura S, Wannanon $P_{\text {, }}$ Jittiwat J. Cerebroprotective effect of Moringa oleifera against focal ischemic stroke induced by middle cerebral artery occlusion. Oxid Med Cell Longev. 2013;2013:951415. doi: 10.1155/2013/951415.

25. Lipton P. Ischemic cell death in brain neurons. Physiol Rev. 1999;79(4):1431-568 doi: 10.1152/physrev.1999.79.4.1431, PMID 10508238

26. Kaewkaen P, Tong-un T, Wattanathorn J, Muchimapura S, Kaewrueng W, Wongcharoenwanakit $S$. Mulberry fruit extract protects against memory impairment and hippocampal damage in animal model of vascular dementia. Evid Based Complement Alternat Med. 2012;2012:263520. doi: $10.1155 / 2012 / 263520$.

27. Omotoso GO, Gbadamosi IT, Afolabi TT, Abdulwahab AB, Akinlolu AA. Ameliorative effects of Moringa on cuprizone-induced memory decline in rat model of multiple sclerosis. Anat Cell Biol. 2018 Jun;51(2):119-27. doi: 10.5115/ acb.2018.51.2.119, PMID 29984057.

28. Giacoppo S, lori R, Bramanti P, Mazzon E. Topical moringin-cream relieves neuropathic pain by suppression of inflammatory pathway and voltage-gated ion channels in murine model of multiple sclerosis. Mol Pain. 2017 Jan-Dec; 13:1744806917724318. doi: 10.1177/1744806917724318, PMID 28741431.

29. Giacoppo S, Rajan TS, De Nicola GR, lori R, Rollin P, Bramanti P, Mazzon E. The isothiocyanate isolated from Moringa oleifera Shows potent anti-inflammatory activity in the treatment of murine subacute Parkinson's disease. Rejuvenation Res. 2017 Feb;20(1):50-63. doi: 10.1089/rej.2016.1828, PMID 27245199.

30. Lee $\mathrm{KH}, \mathrm{Cha} \mathrm{M}$, Lee $\mathrm{BH}$. Neuroprotective effect of antioxidants in the brain Int J Mol Sci. 2020;21(19):7152. doi: 10.3390/ijms21197152, PMID 32998277.

31. Lobo V, Patil A, Phatak A, Chandra N. Free radicals, antioxidants and functional foods: impact on human health. Pharmacogn Rev. 2010;4(8):118-26. doi: 10.4103/0973-7847.70902, PMID 22228951.

32. Pisoschi AM, Pop A. The role of antioxidants in the chemistry of oxidative stress: a review. Eur J Med Chem. 2015;97:55-74. doi: 10.1016/j.ejmech.2015.04.040, PMID 25942353.

33. Bader N, GruneT. Protein oxidation and proteolysis. Biol Chem. 2006;387(10-11): 1351-5. doi: 10.1515/BC.2006.169, PMID 17081106.

34. Lecker SH, Goldberg AL, Mitch WE. Protein degradation by the ubiquitinproteasome pathway in normal and disease states. J Am Soc Nephrol. 2006;17(7):1807-19. doi: 10.1681/ASN.2006010083, PMID 16738015.

35. Lee JH, Lee SR. The effect of baicalein on hippocampal neuronal damage and metalloproteinase activity following transient global cerebral ischaemia. Phytother Res. 2012;26(11):1614-9. doi: 10.1002/ptr.4644, PMID 22344890.

36. Chen P, Li L, Gao Y, Xie Z, Zhang Y, Pan Z, Tu Y, Wang H, Han Q, Hu X, Xin X. $\beta$-carotene provides neuro protection after experimental traumatic brain injury via the Nrf2-ARE pathway. J Integr Neurosci. 2019;18(2):153-61. doi: 10.31083/j. jin.2019.02.120, PMID 31321956.

37. Zhang DD. Mechanistic studies of the Nrf2-Keap1 signaling pathway. Drug Metab Rev. 2006;38(4):769-89. doi: 10.1080/03602530600971974, PMID 17145701.

38. Bose CK. Possible role of Moringa oleifera Lam. root in epithelial ovarian cancer MedGenMedMed.. 2007;9(1):26. PMID 17435633.

39. Faizi S, Siddiqui BS, Saleem R, Siddiqui S, Aftab K, Gilani AH. Isolation and structure elucidation of new nitrile and mustard oil glycosides from Moringa oleifera and their effect on blood pressure. J Nat Prod. 1994;57(9):1256-61. doi: 10.1021/ np50111a011, PMID 7798960.

40. Bhattacharya J, Guha G, Bhattacharya B. Powder microscopy of bark--poison used for abortion: Moringa pterygosperma gaertn. J Indian Forensic Sci. 1978;17(1):47-50. PMID 12262404.

41. Mazumder UK, Gupta M, Chakrabarti S, Pal D. Evaluation of hematological and hepatorenal functions of methanolic extract of Moringa oleifera Lam. root treated mice. Indian J Exp Biol. 1999;37(6):612-4. PMID 10641193.

Article History: Received: 20-06-2021; Revised: 26-08-2021; Accepted: 29-09-2021.

Cite this article: Khan MF, Yadav S, Banerjee S. Review Article on Effects of Moringa on Central Nervous System. J Young Pharm. 2021;13(4):315-9. 